\title{
MIKROORGANISME PATOGEN DAN PARASIT DI DALAM AIR LIMBAH DOMESTIK SERTA ALTERNATIF TEKNOLOGI PENGOLAHAN
}

\author{
Oleh : \\ Nusa Idaman Said dan Ruliasih Marsidi \\ Kelompok Teknologi Pengelolaan Air Bersih Dan Limbah Cair, Pusat Pengkajian Dan Penerapan \\ Teknologi Lingkungan, BPPT
}

\begin{abstract}
Domestic waste are known to be a potential pollutant due to its' organic and inorganic content. It is also harmful for society for its pathogenic microorganism contents such as pathogenic bacteria, viruses, parasitic worms, parasitic protozoa, etc. The lack of domestic waste processing facilities is contributing to the increasing seriousness of this matter.

One of the alternative ways to amend the problem is to process the waste individually or semi-communally by utilizing an aerobic-anaerobic biofilter process. Some of the advantage of utilizing this process is: easy maintenance, low operation cost, relatively lower sludge compared to the activated sludge process, can remove nitrogen and phosphorus, relatively lower air supply requirement for aeration, applicable in processing waste water with large amount of BOD and it can also remove suspended solid (SS).

Results gained from experiments of the "Aerobic-Anaerobic Biofilter Combination" tool prototype, used for processing domestic waste showed that with a hydraulic retention time of 1 to 3 days and a Hydraulic re-circulation ratio (HRR) of 1, is a highly efficient process which is: BOD $84.7 \%$ - 91\%, COD 79.6\%-95.3\%, SS 94.1\% - 95\%, Ammonia (NH4-N) 89.3\%-89.8\%, Detergent (MBAS) $83 \%-87 \%$ and phosphate (PO4) $44,4 \%-47.3 \%$.
\end{abstract}

Kata kunci : Air limbah domestik, patogen, parasit, biofilter, anaerob, aerob.

\section{PENDAHULUAN}

Air limbah kota-kota besar di Indonesia khususnya Jakarta secara garis besar dapat dibagi menjadi tiga yaitu air limbah industri dan air limbah domestik yakni yang berasal dari buangan rumah tangga dan yang ke tiga yakni air limbah dari perkantoran dan pertokoan (derah kemersial). Saat ini selain pencemaran akibat limbah industri, pencemaran akibat limbah domistikpun telah menunjukkan tingkat yang cukup serius. Di Jakarta misalnya, sebagai akibat masih minimnya fasilitas pengolahan air buangan kota (sewerage system) mengakibatkan tercemarnya badan - badan sungai oleh air limbah domistik, bahkan badan sungai yang diperuntukkan sebagai bahan baku air minumpun telah tercemar pula. Dari hasil penelitian yang dilakukan oleh Dinas Pekerjaan Umum (PU) DKI Jakarta bersama-sama dengan Tim JICA (1989), jumlah unit air buangan dari buangan rumah tangga per orang per hari adalah 118 liter dengan konsentrasi BOD ratarata $236 \mathrm{mg} / \mathrm{tt}$ dan pada tahun 2010 nanti diperkirakan akan meningkat menjadi 147 liter dengan konsetrasi BOD rata-rata $224 \mathrm{mg} / \mathrm{lt}$.

Air limbah domestik selain potensial menyebabkan pencemaran badan air akaibat kandungan polutan baik organik maupun anorganiik juga mengandung mikroorganisme patogen yang sangat berbahaya terhadap kesehatan masyarakat. Oleh karena itu perlu penanganan yang lebih serius.

\subsection{Elemen Epidemiologi}

Epimedemiologi adalah studi tentang penyebaran penyakit menular (infeksius) yang terjadi di dalam masyarakat, yang mana penyakit infeksius tersebut dapat menyebar dari satu inang (host) ke inang yang lain.

Kejadian penyakit (incidence of disease) adalah jumlah individu yang terkena penyakit di dalam masyarakat, sedangkan prevalensi (prevalence) adalah prosentase dari individu yang terkena penyakit pada waktu tertentu.

Suatu penyakit disebut epidemik apabila jumlah individu yang terkena penyakit di dalam suatu masyarakat tinggi, dan disebut endemik jika jumlah individu penderita penyakit di dalam masyarakat tersebut rendah.

Pandemik adalah penyebaran penyakit infeksius yang terjadi melintasi benua atau wilayah yang sangat luas sekali.

Infeksi adalah penyerangan suatu inang (host) oleh mikroorganisme yang bersifat 
infeksius, yakni masuknya mikroorganisme patogen ke dalam suatu inang (host) kemudian berkembang biak dan menetap di dalam inang tersebut. Masuknya mikroorganisme patogen ke dalam inang dapat melalui perut atau gastrointestinal, kulit maupun saluran pernafasan.

Infeksi tersamar (tak nyata) atau disebut inapparent infection atau covert infection adalah infeksi tanpa menimbulkan gejala klinis (infeksi subklinis). Di dalam infeksi tersamar tersebut reaksi inang (host) tidak dapat dideteksi secara klinis. Meskipun tidak menyebabkan gejala penyakit infeksi subklinis tersebut memberikan derajad immunitas yang sama sebagai infeksi nyata. Sebagai contoh, hampir sebagaian besar virus enterik menyebabkan infeksi tersamar atau infeksi subklinis. Seseorang yang mengalami infeksi subklinis disebut sebagai pembawa atau penyebar yang sehat (healthy carrier), tetapi merupakan sumber penyebar infeksi yang potensial terhadap individu yang lain di dalam komunitas (Finlay and Falkow, 1989; jawetz et.al., 1984).

Patogenisitas (pathogenicity) adalah kemampuan dari suatu perantara atau agen yang bersifat infeksius yang dapat menyebabkan penyakit terhadap inang (host). Mikroorganisme patogen mungkin akan menginfeksi inang atau host yang rentan (mudah terinfeksi) dan kadangkadang menyebabkan infeksi nyata dengan menimbulkan gejala klinis yang dengan mudah dapat dideteksi. Pertumbuhan penyakit tergantung dari beberapa faktor antara lain dosis infeksi (infectius dose), patogenisitas, inang (host) dan faktor-faktor lingkungan. Tetapi beberapa jenis organisme kemungkinan sebagai organisme patogen dan menyebabkan penyakit hanya terhadap beberapa individu tertentu.

\subsection{Rantai Infeksi}

Potensi dari agen biologis (biological agent) untuk dapat menginfeksi inang atau host yang rentan tergantung dari beberapa faktor yakni sebagai berikut :

\subsubsection{Jenis pembawa infeksi (infectius agent).}

Beberapa organisme kemungkinan dapat menyebabkan penyakit terhadap manusia. organisme tersebut antara lain bakteria, fungi, protozoa, metazoa (helminths), rickettsiae dan virus. Secara garis besar ditunjukkan seperti pada Gambar 1.

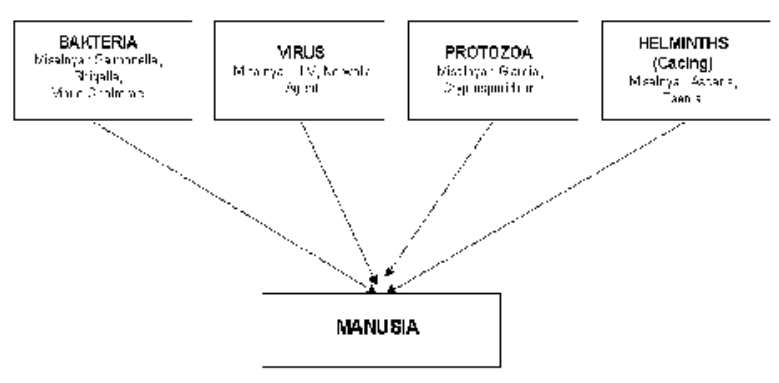

Gambar 1 : Beberapa jenis mikroorganisme patogen yang sangat berhubungan dengan kesehatan masyarakat.

Evaluasi dari organisme atau agen inkeksius tersebut didasarkan pada kemampuan atau potensi untuk menyebabkan penyakit terhadap manusia. Potensi agen untuk menyebabkan penyakit tersebut juga tergantung pada stabilitas dari agen infeksius di dalam lingkungannya. Dosis infeksi minimal (minimal infective dose) bervariasi secara luas tergantung dari jenis dari organisme patogen atau organisme parasitnya. Sebagai contoh, salmonella typhi atau E, Coli enteropatogenik untuk dapat menyebabkan penyakit dosisnya antara ribuan sampai beberapa jutaan, sedangkan dosis infeksi minimal untuk shigella untuk dapat menimbulkan penyakit hanya sekitar sepuluh sel, sementara sejumlah kecil kista (cyst) dari protozoa atau telur helminths sudah cukup untuk dapat menyebabkan infeksi.

Untuk beberapa virus hanya dengan satu atau bebera virus saja sudah dapat menyebabkan infeksi terhadap manusia. Sebagai contoh, echovirus 12 dapat menyebabkan infeksi terhadap manusia hanya dengan 17 partikel virus saja. Dosis infeksi minimal dari beberapa jenis organisme ditunjukkan pada Tabel 1. (Bitton, 1994).

Tabel 1 : Dosis infeksi minimal dari beberapa organisne patogen dan parasit.

\begin{tabular}{|c|l|c|}
\hline No & ORGANISME & $\begin{array}{c}\text { DOSIS INFEKSI } \\
\text { MINIMAL }\end{array}$ \\
\hline 1 & Salmonella Spp. & $10^{4}-10^{7}$ \\
2 & Shigella spp. & $10-10^{2}$ \\
3 & E. Coli & $10^{6}-10^{8}$ \\
4 & Vibrio Cholerae & $10^{3}$ \\
5 & Giardia Lamblia & $10-10^{2} \mathrm{cyst}$ \\
6 & Cryptosporidium & $10 \mathrm{cyst}$ \\
7 & Entamoeba Coli & $10 \mathrm{cyst}$ \\
8 & Ascaris & $1-10 \mathrm{egg}$ \\
9 & Hepatitis A virus & $1-10 \mathrm{PFU}$ \\
\hline
\end{tabular}

Sumber : Bitton 1994. 


\subsubsection{Reservoir Pembawa Infeksi (infectius agent reservoir)}

Reservoir adalah sumber yang hidup atau sumber tak hidup dari agen infeksi yang dapat menyebabkan organisme patogen tetap hidup dan berkembang biak. Tubuh manusia adalah merupakan reservoir dari sejumlah besar organisme patogen, dan kontak individu ke individu dibutuhkan untuk mempertahankan siklus penyakit. Beberapa binatang piaraan atau binatang liar juga berfungsi sebagai reservoir dari penyakit misalnya rabies, brucellosis, tuberculosis, anthrax, leptospirosis, toxoplasmosis. Penyakit-penyakit tersebut disebut juga zoonoses yang dapat berpindah dari binatang ke tubuh manusia. Sumber tak hidup dari agen infeksi misalnya air, air limbah, makanan, atau tanah juga dapat mengandung agen infeksi.

\subsubsection{Cara Perpindahan (Mode Transmision)}

Perpindahan atau transmisi meliputi transpor agen infeksi dari reservoir ke inang (host). hal ini merupakan jaringan yang penting di dalam rantai infeksi. Organisme patogen dapat berpindah dari reservoir ke dalam inang atau host melalui berbagai rute (Sobsey and Olson, 1983), yaitu antara lain :

\section{A. Perpindahan dari orang ke orang (person to person transmision)}

Perpindahan agen infeksi yang paling umum yakni melalui kontak orang ke orang. Contoh yang paling jelas adalah perpindahan penyakit secara seksual, misalnya syphilis, gonorrhea, herpes, dan AIDS. Contoh lain penyakit flu melalui batuk dan bersin yang mengelurakan tetesan kecil yang mengandung agen infeksi. Perpindahan dengan cara ini sering dipakai contoh sebagai perpindahan penyakit dengan cara kontak langsung.

\section{B. Perpindahan melalui air (waterborne transmission)}

Perpindahan penyakit Kholera melalui air telah diketahui pada tahun 1854 oleh John Snow, seorang dokter di Inggris. Snow menunjukkan hubungan antara epidemi kholera dan konsumsi air minum dari sumur Broad Street di London.

Penyakit-penyakit yang berhubungan dengan air disebut penyakit bawaan air (waterborne diseases). Di Amerika Serikat, selama perioda 1971 sampai dengan tahun 1985 telah dilaporkan 502 penyakit bawaan air dengan jumlah penderita sebanyak 111.228 kasus. Gambar 2 menunjukkan bahwa hampir tiga per empat dari jumlah penyakit tersebut disebabkan oleh penggunaan air tanah atau air permukaan yang tidak diolah atau tidak memadai (Craun, 1988).

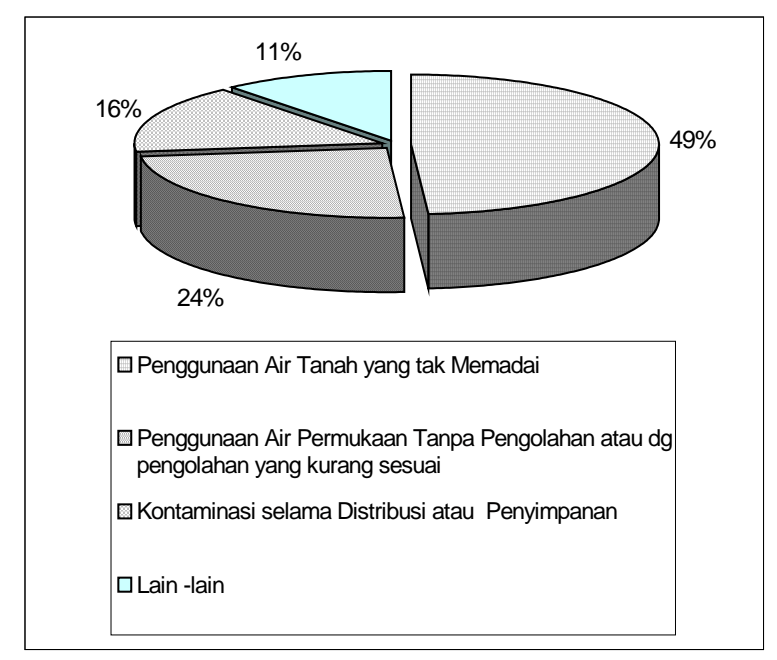

Gambar 2 : Prosesntase penyebab dari 502 jenis penyakit bawaan air di Amerika Serikat selama perioda 1971-1985.

Penyakit gastrointestinal yang tak teridentifikasi secara etiologi dan giardiasis adalah penyakit bawaan air yang paling umum ditemukan di dalam sistem air tanah atau air permukaan. Jenis penyakit bawaan air yang ditemukan tersebut secara lengkap ditunjukkan seperti pada Tebel 2. Sedangkan Tabel 3 menunjukkan laju jumlah penyakit per 1000 water system dan laju jumlah penderita per juta orang per tahun (Craun, 1988). Dari tabel tersebut terlihat bahwa laju jumlah penyakit maupun laju jumlah penderita berkurang apabila air baku diolah atau dilakukan proses disinfeksi.

\section{Perpindahan melalui makanan (Foodborne Transmission)}

Makanan dapat menjadi kendaraan untuk perpindahan dari beberapa jenis penyakit infeksius yang disebabkan oleh bakteria, virus, protozoa, dan parasit helminths (cacing). Kontaminasi makanan dapat disebabkan oleh partikel yang tidak bersih selama penyiapan, produksi atau selama penyimpanan.

Beberapa organisme patogen dan parasit telah dideteksi di dalam bahan makanan misalnya kerang-kerangan, sayuran, susu, telur, daging sapi dan lain-lain. Hal tersebut mempunyai arti yang sangat penting bagi kesehatan masyarakat khususnya untuk makanan yang dimakan secara mentah misalnya kerang dan sayuran. 
Tabel 2 : Etiologi penyakit bawaan air yang disebabkan oleh pengguaan air tanah dan air permukaan.

\begin{tabular}{|l|c|c|}
\hline \multicolumn{1}{|c|}{$\begin{array}{c}\text { Jenis Penyakit } \\
\text { (illnes) }\end{array}$} & $\begin{array}{c}\text { Jumlah } \\
\text { Perjangkitan }\end{array}$ & $\begin{array}{c}\text { Jumlah } \\
\text { Penderita }\end{array}$ \\
\hline $\begin{array}{l}\text { Gastrointeristis (tak } \\
\text { terdefinisikan) }\end{array}$ & 251 & 61.478 \\
Giardiasis & 92 & 24.365 \\
Keracunan Zat & 50 & 3.774 \\
Kimia & 33 & 5.783 \\
Shigellosis & 23 & 737 \\
Hepatitis A & 20 & 6.254 \\
Gastrointeristis, & & 4.983 \\
Virus & 11 & 2.300 \\
Campylobacterosis & 10 & 282 \\
Salmonellosis & 5 & 103 \\
Thypoid (Tipus) & 2 & 1.000 \\
Yersinosis & 1 & 117 \\
Gastroenteristis, & 1 & 17 \\
E.Coli beracun & 1 & 31 \\
Cryptosporidiosis & 1 & 4 \\
Cholera & 1 & $\mathbf{1 1 1 . 2 2 8}$ \\
\hline Dermatitis (penyakit & 1 & \\
kulit) & & \\
Amebiasis & 1 & $\mathbf{5 0 2}$ \\
\hline TOTAL & & \\
\hline Dai: Gratn (1988) & & \\
\hline
\end{tabular}

Dari : Craun (1988)

Tabel 3 : Pengaruh Pengolahan Air Terhadap Jumlah Penyakit dan Jumlah Penderita di Amerika selama perioda 1971-1985

\begin{tabular}{|l|c|c|}
\hline $\begin{array}{c}\text { Tipe Komunitas } \\
\text { Penggunaan Air } \\
\text { Bersih }\end{array}$ & $\begin{array}{c}\text { Jumlah } \\
\text { Penyakit } \\
\text { Bawaan Air } \\
\text { per 1000 } \\
\text { Sistem } \\
\text { Penggunaan } \\
\text { Air }\end{array}$ & $\begin{array}{l}\text { Jumlah } \\
\text { Penderit } \\
\text { a per } \\
\text { satu juta } \\
\text { orang } \\
\text { per } \\
\text { tahun }\end{array}$ \\
\hline $\begin{array}{l}\text { Air permukaan } \\
\text { tanpa pengolahan }\end{array}$ & 32,5 & 370,9 \\
\hline $\begin{array}{l}\text { Air permukaan } \\
\text { dengan disinfeksi } \\
\text { saja }\end{array}$ & 40,5 & 66,3 \\
\hline $\begin{array}{l}\text { Air permukaan } \\
\text { dengan } \\
\text { pengolahan } \\
\text { lpenyaringan dan } \\
\text { disinfeksi }\end{array}$ & 5,0 & 4,7 \\
\hline
\end{tabular}

Sayuran yang telah terkontaminasi oleh air limbah juga menyebakan atau memberi andil terhadap beberapa penyakit misalnya wabah tipus (typhoid fever), salmonellosis, amebiasis, ascariasis, viral hepatitis dan lainnya (Brian, 1977). Resiko terhadap penyakit yang berpindah melalui makanan tersebut biasanya cukup tinggi di negara-negara yang menggunakan irigasi dengan air limbah yang tidak diolah secara memadai.

Kerang-kerangan misalnya tiram, kerang, remis, kepiting dll. merupakan vektor penyakit terhadap manusia yang banyak berperan, agen infeksi yang dibawanya adalah bakteria, virus, protozoa, dan cacing (helmiths). Binatangbinatang tersebut merupakan alat perpindahan penyakit yang perlu diperhatikan karena beberapa alasan yakni (Bitton, 1980a) :

- Binatang tersebut hidup di lingkungan muara yang mana sering terkontaminasi oleh air limbah domestik.

- Oragnisme patogen atau parasit dapat terkonsentrsi di dalam tubuhnya karena binatang-binatang tersebut memompa sejumlah besar air (4-20 Lt per jam), sehingga berfungsi seperti filter.

- Binatang tersebut sering dimakan dalam keadaan mentah atau setengah matang.

Bahaya lain terhadap kesehatan yang berhubungan dengan kerang-kerangan adalah akibat dari kemampuan binatang tersebut untuk mengkonsentrasikan atau mengakumulasikan zat racun dinoflagellate, logam berat, hidrokarbon, pestisida dan zat radio aktif di dalam tubuhnya.

\section{Perpindahan melalui udara (airborne transmission)}

Beberapa jenis penyakit misalnya penyakit yang disebabkan oleh fungi dapat menyebar atau berpindah melalui udara (airborne transmission). Perpindahan melalui udara dapat terjadi pada pengolahan air limbah atau dari irigasi dengan menggunakan efluen air limbah.

\section{E. Perpindahan melalui vektor (Vektor- borne Transmission)}

Vektor-vektor yang paling penting di dalam perpindahan penyakit antara lain adalah : arthropoda misalnya kutu dan serangga, atau vertebrata misalnya hewan pengerat, anjing, kucing dll. Organisme patogen mungkin tidak berkembang biak di dalam vektor arthropoda tersebut. Beberapa penyakit yang berpindah melalui vektor antara lain malaria (dari plasmodium), penyakit kuning dan encephalitis (keduanya dari arbovirus), dan rabies (dari virus rabies yang berpindah dari gigitan anjing atau kucing).

\section{F. Lain-lain (Fomites)}


Beberapa penyakit juga dapat berpindah melalui objek tak hidup misalnya melalui pakaian, mainan anak, peralatan dapur, alat suntik dan lain-lain.

\section{I.2.4 Pintu Masuk Mikroorganisme Patogen atau Parasit}

Mikroorganisme patogen dapat atau mempunyai akses ke inang (host) melalui saluran gastrointestinal misalnya virus enterik dan bakteria, melalui saluran pernafasan misalnya klebsiella pneumonae, legionella, dan myxovirus, atau melalui kulit misalnya aeromonas, clostridium tetani, dan clostridium perfrigens. Meskipun kulit merupakan hambatan yang kuat bagi organisme patogen, tetapi luka, abrasi atau iritasi dapat menyebabkan penetrasi organisme patogen tersebut ke dalam tubuh (host).

\section{I.2.5 Kerentanan Inang (Host Susceptibility)}

Baik sistem kekebalan tubuh ataupun faktor-faktor yang tidak khusus, keduanya memainkan peranan di dalam ketahanan inang terhadap agen infeksi (infectius agent). Kekebalan terhadap agen infeksi tersebut mungkin di dapat secara alami atau diperoleh melalui kekebalan buatan (acuired immunity). Kekebalan alami ditentukan secara genetik dan bervariasi sesuai dengan species, ras, umur (biasanya yang lebih muda atau tua lebih rentan terhadap infeksi), status hormonal, dan kesehatan fisik atau mental dari inangnya.

Masyarakat yang tingkat kesehatannya rendah atau kaum usia lanjut lebih retan terhadap agen infeksi dibandingkan dengan golongan dewasa yang sehat. Kekebalan buatan terjadi sebagai akibat pemaparan (exposure) inang ke agen infeksi. Kekebalan buatan tersebut dapat bersifat pasive misalnya janin yang memperoleh antibodi dari ibunya, atau dapat bersifat aktif misalnya produksi antibodi aktif melalui kontak dengan agen infeksi.

Faktor nonspesifik meliputi hambatan atau barrier secara physiologis pada pintu masuknya agen infeksi misalnya $\mathrm{pH}$ yang kurang menguntungkan, garam empedu, produksi enzym pencernaan dan senyawa kimia yang bersifat anti mikroba, kompetisi dengan mikroflora di dalam usus dan lain-lain.

\section{MIKROORGANISME PATOGEN ATAU PARASIT DI DALAM AIR LIMBAH DOMESTIK}

Beberapa mikroorganisme patogen dan parasit biasanya ditemukan di dalam air limbah domestik dan juga di dalam efluen dari unit pengolahan air limbah. Beberapa penyakit yang disebabkan oleh agen infeksi yang sering ditemukan didalam air limbah antara lain adalah sebagai berikut.

\subsection{Bakteria Patogen}

Tinja atau kotoran binatang (fecal matter) mengandung lebih dari $10^{12}$ bakteria per gram. Kandungan bakteria di dalam tinja (feces) mencapai kira-kira $9 \%$ dari berat basah (Dean and Lund, 1981). Bakteria yang ada di dalam air limbah telah diklasifikasikan menjadi beberapa grup yakni :
1. Bakteria gram-negative fakultative anaerobik misalnya Aeromonas, Plesiomonas, Vibrio, Enterobacter, Escherichia, Klebsiella dan Shigella.

2. Bakteria gram-negative aerobik misalnya Pseudomonas, Alcaligenes, Flavobacterium, dan Acinetobacter.

3. Bakteria gram-positive pembentuk spora misalnya Bacillus spp.

4. Bakteria gram-positive non spora misalnya Arthrobacter,Corynebacterium,

Rhodococcus.

Kompilasi dari bakteria yang terpenting yang mungkin bersifat patogen terhadap manusia dan yang dapat berpindah baik secara langsung atau tak langsung melalui air limbah ditunjukkan pada Tabel 4.

Tabel 4 : Penyakit bawaan air yang disebabkanoleh bakteria.

\begin{tabular}{|c|c|c|c|c|}
\hline No & $\begin{array}{c}\text { Agen } \\
\text { Bakteria }\end{array}$ & $\begin{array}{l}\text { Penyakit } \\
\text { Utama }\end{array}$ & $\begin{array}{c}\text { Reservoir } \\
\text { utama }\end{array}$ & $\begin{array}{c}\text { Daerah yang } \\
\text { diserang }\end{array}$ \\
\hline 1 & $\begin{array}{l}\text { Salmonella } \\
\text { typhi }\end{array}$ & $\begin{array}{l}\text { Demam } \\
\text { Typhoid } \\
\text { (Tiphus) }\end{array}$ & $\begin{array}{l}\text { Tinja } \\
\text { manusia }\end{array}$ & $\begin{array}{l}\text { Saluran } \\
\text { Gastrointestinal }\end{array}$ \\
\hline 2 & $\begin{array}{l}\text { Salmonella } \\
\text { paratyphi }\end{array}$ & $\begin{array}{l}\text { Demam } \\
\text { paratyphoid } \\
\text { (paratiphus) }\end{array}$ & $\begin{array}{l}\text { Tinja } \\
\text { manusia }\end{array}$ & $\begin{array}{l}\text { Saluran } \\
\text { Gastrointestinal }\end{array}$ \\
\hline 3 & Shigella & Dysentri basiler & $\begin{array}{l}\text { Tinja } \\
\text { manusia }\end{array}$ & Intestine bawah \\
\hline 4 & $\begin{array}{l}\text { Vibrio } \\
\text { cholerae }\end{array}$ & Kholera & $\begin{array}{l}\text { Tinja } \\
\text { manusia }\end{array}$ & $\begin{array}{l}\text { Saluran } \\
\text { Gastrointestinal }\end{array}$ \\
\hline 5 & $\begin{array}{l}\text { Enteropatho } \\
\text { genie E. Coli }\end{array}$ & Gastroenteritis & $\begin{array}{l}\text { Tinja } \\
\text { manusia }\end{array}$ & $\begin{array}{l}\text { Saluran } \\
\text { Gastrointestinal }\end{array}$ \\
\hline 6 & $\begin{array}{l}\text { Yersinia } \\
\text { enterocolitica }\end{array}$ & Gastroenteritis & $\begin{array}{l}\text { Kotoran } \\
\text { hewan atau } \\
\text { manusia }\end{array}$ & $\begin{array}{l}\text { Saluran } \\
\text { Gastrointestinal }\end{array}$ \\
\hline 7 & $\begin{array}{l}\text { Champyloba } \\
\text { cter jejuni }\end{array}$ & Gastroenteritis & $\begin{array}{l}\text { Kotoran } \\
\text { hewan atau } \\
\text { manusia }\end{array}$ & $\begin{array}{l}\text { Saluran } \\
\text { Gastrointestinal }\end{array}$ \\
\hline 8 & $\begin{array}{l}\text { Legionella } \\
\text { pneumophila }\end{array}$ & $\begin{array}{l}\text { Penyakit } \\
\text { pernafasan } \\
\text { akut }\end{array}$ & Air panas & Paru-paru \\
\hline 9 & $\begin{array}{l}\text { Mycobacteri } \\
\text { um } \\
\text { tuberculosis }\end{array}$ & Tuberculosis & $\begin{array}{l}\text { Dahak/ludah } \\
\text { atau } \\
\text { pernafasan } \\
\text { manusia }\end{array}$ & Paru-paru \\
\hline 10 & Leptospira & Leptospirosis & $\begin{array}{l}\text { Air kencing } \\
\text { dan kotoran } \\
\text { hewan }\end{array}$ & Umum \\
\hline 11 & $\begin{array}{l}\text { Opportunistik } \\
\text { bakteria }\end{array}$ & Variabel & Air alam & $\begin{array}{l}\text { Umumnya saluran } \\
\text { pencernaan }\end{array}$ \\
\hline
\end{tabular}

Disesuaikan dari Sobsey dan Olson (1983). 
Bakteria-bakteria tersebut menyebabkan infeksi interik misalnya wabah tipus, kholera, dan shigellosis.

Beberapa mikroorganisme patogen yang penting yang ada di dalam air limbah antara lain sebagai berikut :

\subsubsection{Salmonella}

Salmonella adalah enterobacteriaceae yang terdistribusi secara luas di dalam lingkungan, dan meliputi lebih dari 2000 stereotipe. Salmonella merupakan bakteria patogen yang paling utama yang terdapat di dalam air limbah, yang dapat menyebabkan demam tipus dan paratipus, dan gastroenteristis (radang lambung/perut).

Konsentrasi salmonella di dalam air limbah berkisar dari beberapa sel sampai mencapai 8000 organisme per $100 \mathrm{ml}$ air limbah (Feachem et.al., 1983). Diperkirakan bahwa hampir $0,1 \%$ dari penduduk mengeluarkan salmonella di dalam tinja. Di Amerika Serikat, salmonellosis terutama disebabkan karena kontaminasi makanan, tetapi transmisi lewat air minum masih menjadi perhatian yang utama (Sobsey and Olson, 1983).

Salmonella typhi adalah agen infeksi demam tipus, suatu penyakit yang tidak segera diobati dapat menyebabkan kematian. Penanggulangan penyakit tersebut telah dilakukan dengan cara menggunakan teknologi proses pengolahan air yang memadai misalnya dengan filtrasi dan khlorinasi. Salmonella thypi tersebut menghasilkan endotoxin yang dapat menyebabkan demam, mual dan diare, dan dapat berakibat fatal apabila tidak diobatai dengan antibiotik (Sterrit and Lester, 1988). Species salmonella yang sering terdapat pada makanan yang terkontaminasi antara lain yakni salmonella paratyphi dan salmonella typhimurium. Species tersebut dapat tumbuh dengan cepat di dalam makanan yang terkontaminasi tersebut. Species salmonella seperti $S$. typhimurium dan $S$. enteriditis dapat menyebabkan gastroenteristis (radang lambung) dengan gejala diare dan kejang perut.

\subsubsection{Shigella}

Shigella secara sepintas adalah agen disentri bacillus, suatu penyakit diare yang menyebabkan berak darah sebagai akibat peradangan dan pendarahan selaput atau dinding usus. Ada empat species shigella yang bersifat patogen yakni Shigella flexneri, Shigella dysentriae, Shigella boydii, dan Shigella sonnei. Ke empat shigella patogen tersebut dapat berpindah dengan cara kontak langsung dengan penderita yang telah terinfeksi, yang mana orang yang terkena infeksi mengeluarkan shigella di dalam tinjanya dengan konsentrasi lebih dari $10^{9}$ shigella per gram tinja. Dosis infeksi dari shigella relaitif kecil yakni sekitar 10 organisme.

Meskipun perpindahan atau penularan shigella melalui kontak orang ke orang adalah merupakan moda penularan yang utama, tetapi penularan melalui makanan atau melalui air juga perlu diperhatikan. Sebagai contoh, telah diketahui bahwa penggunaan air tanah mempunyai andil terhadap shigellosis yang terjadi di Florida, yang telah menginfeksi sekitar 1200 orang. Meskipun demikan shigella kurang tahan di lingkungan dibandingkan dengan fecal coliforms. Shigella sangat sulit dikultivasi (dibiakkan), oleh karena itu belum ada data secara kuantitatif tentang kehadirannya dan efisiensi penghilangan pada instalai penjernihan air maupun instalsi pengolahan air limbah.

\subsubsection{Vibrio Cholerae}

Vibrio cholerae adalah bakteri gramnegative yang berbentuk batang melengkung (curved rod), bakteri ini berjangkit atau berpindah melalui air. Vibrio cholerae mengeluarkan atau melepaskan suatu enterotoxin yang menyebabkan diare ringan sampai diare hebat, muntah, dan menyebabkan kehilangan cairan dengan cepat, serta dapat menyebabkan kematian dalam waktu yang relatif singkat (Sterritt and Lester, 1988). Meskipun jarang ditemukan di Amerika atau Eropa, vibrio cholerae sering muncul sebagai endemik di banyak wilayah di Asia.

Organisme patogen tersebut terdapat di dalam air limbah dengan konsentrasi berkisar antara $10-10^{4}$ organisme per $100 \mathrm{ml}$ air limbah pada saat terjadi endemik (Kott and Betzer, 1972). Ledakan endemik cholera dan demam tipus telah di dokumentasikan di Peru dan Chili, yang disebabkan mengkonsumsi sayuran yang telah terkontaminasi oleh air limbah domestik (Shuval, 1992). Vibrio cholerae juga secara alamiah terdapat di alam dan melekat pada tanah atau padatan, termasuk zooplankton (misal, copepod) dan phytoplankton (misalnya volvox). Bakteria yang bergabung dengan phytoplankton tersebut berada dalam kondisi yang tak dapat dibiakkan (nonculturable state) dan dapat dilihat dengan mikroskop dengan cara teknik fluorecent-monoclonal antibody (Brayton et.al., 1987).

\subsubsection{E. Coli}

Banyak strain E. coli yang beberapa diantaranya tidak berbahaya, terdapat pada saluran gastrointestinal pada manusia atau hewan berdarah panas. Tetapi ada beberpa kategori E. Coli yang bersifat beracun, dan dapat menyebabkan diare. Ada beberpa strain $\mathrm{E}$. 
Coli yang bersifat enterotoxigenic (ETEC), enteropathogenic (EPEC), enterohemorrhagic (EHEC), dan enteroinvasive (Levine, 1987).

$$
\text { E. Coli enterotoxigenic dapat }
$$

menyebabkan radang lambung (gastroenteristis) dan diare yang hebat disertai dengan kram perut dan muntah-muntah (Harris, 1986). Kira-kira 2\% - $8 \%$ dari E. Coli yang terdapat di dalam air bersifat enteropathogenic yang dapat menyebabkan diare. Air dan makanan merupakan faktor penularan atau penyebaran dari E. Coli tersebut. Dosis infeksi dari E. Coli jenis ini relatif tinggi yakni berkiasar antara $10^{6}$ $10^{9}$ organisme. Beberapa jenis E. Coli yang bersifat diarrheagenic telah dideteksi di dalam air yang telah diproses (treated water), dan hal ini menunjukkan resiko kesehatan terhadap konsumen.

\section{1.5 Yersina}

Yersina.enterocolica adalah penyebab gastroenteritis akut, binatang pembawanya terutama adalah babi hutan, namun binatang peliharaan atau binatang buas yang lainnya kadangkala menjadi pembawa patogen ini. Keterlibatan air dengan patogen ini masih belum jelas, namun ada sebuah contoh yang disebutkan oleh Schiemen, 1990, bahwa air dapat menyebarkan gastroenteritis. Organisme psychrotrophic berkembang biak dan subur hingga suhu terendah $4^{\circ} \mathrm{C}$.

\subsubsection{Campylobacter}

Patogen ini dikenal dapat menginfeksi manusia, binatang buas dan binatang peliharaan. Patogen ini dapat menyebabkan gastroenteritis akut (demam, pusing, sakit perut, diare, mual) dan beralih ke tubuh manusia melalui makanan yang terkontaminasi, terutama daging unggas dan air yang terkontaminasi. Air ledeng seperti juga aliran air dari gunung dapat merupakan sumber infeksi.

Campylobacte terdeteksi pada air permukaan, air minum dan air buangan, namun belum pernah terdeteksi pada lumpur. Jumlah organisme campylobacter tidak dapat ditunjukkan atau dihubungkan dengan heterotrophic plate counts, total dan fecal coliforms atau fecal streptococci.

\subsubsection{Leptospira}

Leptospira adalah spirochete kecil yang dapat masuk ke dalam tubuh manusia melalui luka pada kulit atau melalui selaput lendir. Penyakit yang disebabkan oleh leptospira disebut leptospirosis, yang mempunyai karakter terjadinya diseminasi patogen dalam darah tubuh pasien dan berikutnya terjadi infeksi pada ginjal dan pada sistem pusat saraf. Wabah ini dapat ditularkan dari binatang (binatang pengerat, binatang peliharaan dan binatang buas) ke manusia melalui kontak (misal mandi) menggunakan air yang telah terkontaminasi oleh kotoran binatang.

Patogen ini tidak menjadi perhatian utama karena patogen ini tidak mudah hidup dalam air buangan.

Masa inkubasi penyakit ini antara dua hari hingga 26 hari, tetapi umumnya antara 7 sampai 13 hari. Mulai hari ke dua akan terlihat gejala seperti demam tinggi, kepala pusing, mata kuning, air kencing berwarna seperti teh, timbul rasa nyeri pada otot tungkai bawah dan mata berwarna merah. Wabah ini dapat mengenai pekerja galian saluran air. Namun patogen ini tidak merupakan perhatian utama karena patogen ini tidak mudah hidup dalam air buangan.

$\mathrm{Di}$ Indonesia, Leptospira ditemukan pertama kali pada orang-orang yang bekerja di perkebunan karet sewaktu penjajahan belanda pada tahun 1920. Selanjutnta tahun 1940, Prof Suratno menemukan leptospira pada hewan babi di Jakarta. Kuman penyakit ini kemudian diisolasi yang selanjutnya disebut leptospira interrogans serovar pomona (Republika Minggu 17 Maret 2002). Sampai saat ini total serovar leptospira yang ditemukan Balitvet Bogor berjumlah 16 jenis.

\subsubsection{Legionella Pneumophila}

Bakteri legionella pneumophila adalah pembawa penyakit legionnaire (etiological agent), pertama dikemukakan pada tahun 976 di Philadelphia, Pennsylvania. Penyakit ini semacam penyakit pneumonia akut, yang kadang kala melibatkan gastrointestinal dan saluran air kencing, juga dengan sistem urat syaraf. Infeksi. Gejala yang terjadi pada infeksi ini adalah suhu badan naik, sakit kepala dan sakit otot, namun akan membaik dengan sendirinya tanpa perlu penanganan. Organisme ini berpindah melalui aerosolization.

Penularan penyakit legionnaire berhubungan dengan terjadinya pemaparan dengan microbial aerosol yang berasal dari cooling tower (menara pendingin), evaporative condenser, humidifier dan shower. Menara pendingin biasanya mendinginkan air panas yang dihasilkan dari pembangkit tenaga. Bagian atas menara pendingin ini menyebarkan microbial aerosol, termasuk legionella, Diperkirakan bahwa sumber legionella adalah air yang mengalir dari air permukaan terdekat atau dari air minum yang digunakan untuk menggantikan uap air yang hilang pada saat proses pendinginan. 
Seseorang dapat terjangkit penyakit nosocomial legionella apabila terkena legionella melalui sistem distribusi air di rumah sakit. Air minum merupakan sumber wabah penyakit legionnaire di rumah sakit. Jumlah kasus bertambah sejalan dengan penurunan tekanan pada sistem distribusi, yang kemungkinan terjadi pelepasan sel legionella dari lapisan biofilm yang tumbuh pada pipa distribusi. Namun demikian kasus berkurang sejalan dengan hiperkhlorinasi (>2 mg/l sisa khlor bebas).

Bakteri ini terdapat dimana-mana dan berasal dari air buangan, tanah dan lingkungan perairan. Pada lingkungan yang biasa patogen ini dapat berkembang berdampingan dengan bakteri lain seperti ganggang hijau dan ganggang biru-hijau, amuba atau ciliates, sebagai hasil dari meningkatnya kekebalan terhadap biocides, khlorinasi, ph rendah dan temperatur tinggi.

\subsubsection{Bacteroides Fragilis}

Strain produksi enterotoxin dari bakteri anaerobik ini merupakan penyebab diare pada manusia. Patogen ini ditemukan pada air buangan pada tingkat berkisar dari $6,2 \times 10^{4}$ sampai $1,1 \times 10^{5} \mathrm{CFU} / \mathrm{ml}, 9,3 \%$ adalah enterotoxigenic.

\subsubsection{Opportunistic Bacterial Pathogens}

Dalam grup ini termasuk bakteri gram negatif heterotropic yaitu: pseudomonas, klebsiella, flavobacterium, enterobacter, proteus dan providencia. Segmen masyarakat yang berisiko terkena infeksi opportunistic pathogen adalah bayi yang baru lahir, orang lanjut uisia dan orang yang dalam keadaan sakit. Organisme ini banyak terdapat dalam air minum dan pada pipa distribusi air di gedung-gedung seperti rumah sakit. Opportunistic pathogen lainnya adalah nontubercular mycobacteria yang dapat menyebabkan sakit paru-paru (pulmonary) dan penyakit lainnya. Yang paling sering diteliti dari jenis nontubercular mycobacteria adalah species mycobacterium avium-intracellulare. Air minum terutama di rumah sakit dapat mendorong pertumbuhan bakteri ini yang kemungkinan berkaitan dengan infeksi nosocomial.

\subsection{Bakteria Pembentuk Antibiotik (Antibiotic Producing Bacteria)}

Penderita yang menerima pengobatan antibiotik menyimpan sejumlah besar bakteri kebal antibiotik pada saluran ususnya. Bakteri ini terbawa keluar dalam jumlah besar dalam kotoran manusia dan akhirnya masuk ke dalam instalasi pengolahan air buangan. Faktor kekebalan terhadap antibiotik terdapat pada plasmids ( $\mathrm{R}$ faktor) dan pada kondisi yang tertentu dapat berpindah ke bakteri lain melalui suatu hubungan kontak antar sel. Apabila bakteri penerima adalah patogen potensial, maka akan menjadi masalah bagi kesehatan masyarakat sebagai akibat timbulnya kekebalan terhadap antibiotik pada patogen tersebut. Microorganisme yang kebal obat menghasilkan nosocomial dan kumpulan penyebab infeksi pada manusia, yang dapat menyebabkan peningkatan wabah penyakit dan kematian. Kebal obat pada bakteri akan menyebabkan kenaikan biaya pengobatan.

Strategi untuk menanggulangi masalah ini adalah mengurangi penggunaan antibiotik pada manusia dan hewan serta mencari cara pencegahan terhadap penularan penyakit infeksi. Bakteri yang tahan terhadap antibiotik telah terdeteksi pada lingkungan daratan dan lingkungan air, terutama pada lokasi yang terkontaminasi oleh buangan rumah sakit.

Faktor pembawa antar microorganisme diketahui terdapat pada lingkungan alamiah maupun pada lingkungan hasil rekayasa seperti instalasi pengolahan air limbah. Peneliti menggunakan ruang terlindung untuk memperlihatkan perpindahan plasmid $\mathrm{R}$ diantara bakteri dalam air buangan domestik. Frekwensi perpindahan rata-rata dalam air buangan bervariasi antara $4,9 \times 10^{-5}$ dan $7,5 \times 10^{-5}$. Frekwensi perpindahan paling tinggi $\left(2,7 \times 10^{-4}\right)$ terjadi antara Salmonela enteritidis dan E.coli. Plasmid non penghubung (misal pBR plasmid) dapat juga sebagai perantara, namun memerlukan kehadiran bakteri penggerak sebagai media pemindah. Beberapa bakteri penggerak telah diisolasi dari air buangan. Setiap bakteri ini mampu membantu perpindahan plasmid pBR325 ke penerima bakteri e.coli.

Telah ditemukan adanya indikator dan patogen multiple-antibiotic-resistant (MAR) (misal salmonela) dalam instalasi air bersih dan air buangan. Dalam air buangan yang belum diolah, presentasi multiple-antibiotic-resistant coliform bervariasi antara kurang dari $1 \%$ hingga kira-kira 5\% dari total coliform. Khlorinasi bekerja untuk menghilangkan bakteri kebal antibiotik pada instalasi pengolahan air buangan. Namun peneliti lain melaporkan bahwa khlorinasi menaikkan kekebalan bakteri terhadap beberapa antibiotik (seperti ampicilin, tetracycline) tapi tidak terhadap yang lainnya. Perbandingan bakteri pembawa faktor $R$ bertambah mengikuti proses pengolahan air dan air buangan. Sebagai contoh, dalam suatu studi MAR diharapkan sebesar $18,6 \%$ dari bakteri heterotrophic plate count dalam air yang belum diolah dibandingkan dengan nilai $67,8 \%$ untuk bakteri dalam sistem distribusi. Serupa dalam instalasi pengolahan air 
di Oregon, presentasi MAR 15,8\% dalam air yang belum diolah (dalam sungai) dibandingkan dengan nilai $57,1 \%$ dalam air yang telah diolah. MAR selanjutnya dihubungkan dengan kekebalan terhadap logam berat (misal $\mathrm{Cu}^{2+}$, $\left.\mathrm{Pb}^{2+}, \mathrm{Zn}^{2+}\right)$. Phenomena ini telah dibuktikan dalam air minum dan air buangan. Efek terhadap kesehatan masyarakat terhadap penomena ini belum banyak diketahui.

\subsection{Virus}

Air dan air limbah dapat terkontaminasi oleh sevabyak 140 jenis virus perut. Virus ini masuk ke dalam tubuh manusia melalui mulut dan berkembang baik dalam saluran pencernaan dan kemudian dikeluarkan dalam jumlah yang besar melalui kotoran manusia yang terinfeksi.

Tabel 5 (Bitton, 1980a; Jehl-Pietri, 1992; Schwartzbrod, 1991; Schwartzbrod et al., 1990) memperlihatkan daftar enteric virus (virus perut) yang ditemukan dalam lingkungan perairan yang bersifat patogen terhadap manusia.

Tabel 5 : Beberapa virus enteric pada manusia

\begin{tabular}{|c|c|c|c|}
\hline & Grup Virus & $\begin{array}{l}\text { Sero } \\
\text { type }\end{array}$ & Penyakit yang disebabkan oleh Virus \\
\hline \multirow[t]{6}{*}{ A. } & Entero Virus : & & \\
\hline & Poliovirus & 3 & Paralysis, aseptic meningitis \\
\hline & Coxsackievirus A & 23 & $\begin{array}{l}\text { Herpangia, aseptic meningitis, } \\
\text { penyakit pernafasan, paralysis, } \\
\text { demam }\end{array}$ \\
\hline & Coxsackievirus B & 6 & $\begin{array}{l}\text { Pleurodynia, aseptic meningitis, } \\
\text { radang selaput jantung (pericarditis), } \\
\text { penyakit hati bawaan, anomali, } \\
\text { radang ginjal (nephritis), demam }\end{array}$ \\
\hline & Echovirus (68-71) & 34 & Meningitis, penyakit pernafasan \\
\hline & $\begin{array}{l}\text { Virus hepatitis A } \\
\text { (HAV) }\end{array}$ & 4 & Infeksi hepatitis \\
\hline B. & Reovirus & 3 & Penyakit pernafasan \\
\hline $\mathrm{C}$. & Rotavirus & 4 & Gastroenteristis \\
\hline D. & Adenovirus & 41 & $\begin{array}{l}\text { Penyakit pernafasan, conjunctivitis } \\
\text { akut, gastroenteristis }\end{array}$ \\
\hline E. & $\begin{array}{l}\text { Norwalk agent } \\
\text { (calicivirus) }\end{array}$ & 1 & Gastroenteristis \\
\hline F. & Astrovirus & 5 & Gastroenteristis \\
\hline
\end{tabular}

Disesuaikan dari Bitton (1980), Jehl-Pietri (1992), dan Schwartzbrod (1990).

Virus-virus yang masuk tersebut kadangkala menyebabkan infeksi yang tidak terlihat, sehingga sulit dideteksi. Virus ini penyebab penyakit yang sangat luas spektrumnya yang bervariasi mulai dari penyakit kulit, demam, infeksi pernafasan, penyakit yang berhubungan dengan pencernaan dan kelumpuhan.

Virus perut relatif berjumlah sedikit dalam air buangan, namun demikian sampel sebanyak 10 - 1000 liter harus dipekatkan untuk mendeteksi patogen ini. Pendekatan dalam menentukan angka patogen ini telah diperoleh.
Pendekatan yang paling banyak dilakukan adalah berdasarkan pada adsorpsi virus ke dalam pori-pori mikro saringan yang terbuat dari bermacam-macam komposisi bahan (nitroselulose, fiberglass, epoxy-fiberglass, modifikasi celulosa, celulose + glass fibers), selanjutnya virus yang teradsorbsi diambil dari permukaan filter, konsentrasi sampel diperoleh dengan menggunakan saringan membran atau dengan flokulasi organik. Konsentrat kemudian diuji dengan jaringan kultur binatang.

Ditinjau dari ilmu epidemi, virus perut umumnya berpindah melalui kontak orang ke orang. Namun dapat pula menular melalui perantara air baik langsung (air minum, kolam renang) maupun tidak langsung melalui makanan yang terkontaminasi. Penularan waterborne virus perut digambarkan pada Gambar 3.

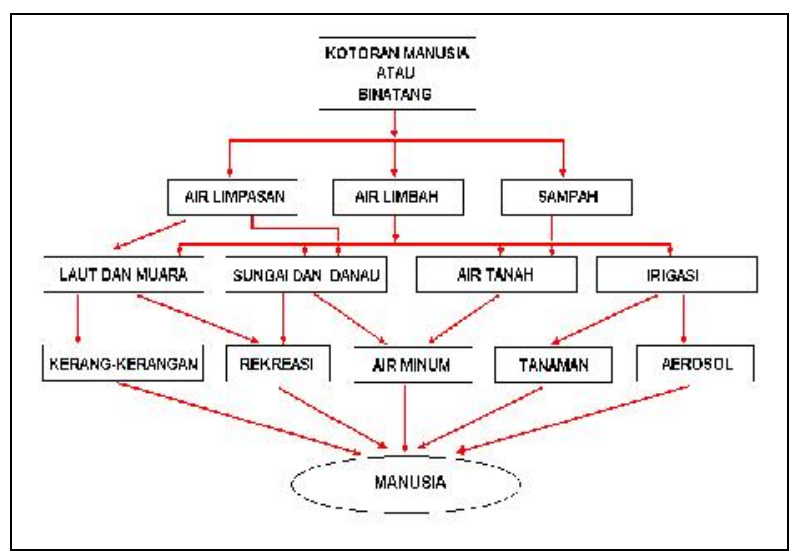

Gambar 3 : Penyebaran virus perut (entericviruses) melalui air (waterborne).

Proses infeksi tergantung pada dosis efektif minimal (MID) dan pada host yang mudah tertular, dalam hal ini menyangkut faktor host (imunitas spesifik, jenis kelamin, umur) dan faktor lingkungan (misal tingkat sosial-ekonomi, kondisi kebersihan, temperatur, kelembaban). Walaupun MID virus masih kontroversial, secara umum relatif rendah dibandingkan dengan bakteri patogen. Percobaan pada manusia menunjukkan MID 17 PFU (plaque-forming units) untuk echovirus 12. Beberapa penelitian epidemi menunjukkan bahwa virus perut merupakan penyebab $4,7 \%-11 \%$ epidemi waterborne. Penyelidikan dibuktikan terhadap penularan waterborne dan foodborne dari penyakit virus seperti hepatitis dan penyakit pencernaan.

\subsubsection{Hepatitis}

Terdapat beberapa jenis penyakit Hepatitis, masing-masing disebabkan oleh jenis virus yang berbeda. Beriku adalah jenis-jenis virus penyebab hepatitis. 
Infeksi hepatitis disebabkan oleh virus hepatitis A (HAV), yaitu enterovirus 27-nm RNA, dengan masa inkubasi relatif pendek (2-6 minggu) dan penularan melalui fecal-oral. Virus ini sulit dideteksi walaupun dapat dibiakan dalam jaringan namun tidak selalu mempunyai efek cytopathic. Cara lain untuk mendeteksi HAV adalah dengan peyelidikan genetik dan metode imunologi (immunoelectron microscopy, radioimmunoassay, enzyme immunoassay, radioimmunofocus assay).

Serum hepatitis disebabkan oleh virus hepatitis B (HBV), yaitu virus 42-nm DNA, mempunyai masa inkubasi relatif lama (4-12 minggu). Virus ini ditularkan melalui kontak dengan darah yang terinfeksi atau melalui hubungan sex. Kematian (1\% - 4\%) lebih tinggi dari pada infeksi hepatitis $(<0,5 \%)$.

Non-A,non-B viral hepatitis disebabkan oleh 2 jenis virus : yaitu 50-nm sampai dengan 60-nm flavivirus dengan karakteristik klinik dan epidemi sama dengan virus hepatitis $B$ dan 32$\mathrm{nm}$ sampai dengan 34-nm calicivirus yang karakteristiknya sama dengan virus hepatitis $A$.

Chronic delta hepatitis yang disebabkan oleh virus 28-nm hingga 35-nm RNA namun belum diketahui secara lengkap mengenai karakteristiknya. Pola klinik dan epideminya sama dengan virus hepatitis $B$.

HAV menyebabkan kerusakan liver dengan terjadinya peradangan. Setelah terjadi infeksi, masa inkubasi berlangsung hingga 6 minggu. Salah satu simptom adalah kulit terlihat kuning.

Hepatitis A menular melalui fecal-oral baik melalui kontak antar orang ke orang maupun melalui waterborne atau food-borne. Penyakit ini menyebar di seluruh dunia dan antibodi HAV lebih banyak terdapat pada kelompok dengan tingkat sosial-ekonomi rendah, kemudian meningkat sesuai umur orang yang terinfeksi. Penularan melalui air tercatat di seluruh dunia kasus hepatitis ini terjadi akibat mengkonsumsi air yang pengolahannya tidak sempurna. Penularan melalui makanan lebih menjadi perhatian dibandingkan melalui air. Mengkonsumsi kerang-kerangan yang tumbuh dalam air buangan yang terkontaminasi menimbulkan kasus hepatitis cukup besar, catatan yang terjadi di seluruh dunia dapat dilihat pada Tabel 6.

\subsubsection{Viral Gastroenteristis}

Penyakit perut merupakan penyakit menular yang paling sering terjadi. Penyakit ini disebabkan oleh parasit protozoa, bakteri patogen dan virus patogen (misal rotavirus dan agen tipe-Norwalk). Berikut ini akan dibahas rotavirus dan virus tipe Norwalk sebagai penyebab penyakit perut.

\section{Rotavirus.}

Rotavirus termasuk dalam keluarga Reoviridae, partikel $70-\mathrm{nm}$ yang mengandung RNA double-stranded dikelilingi double-shelled capsid. Rotavirus adalah penyebab utama penyakit perut akut pada anak dibawah umur 2 tahun. Penyakit ini banyak menyebabkan kematian anak-anak di negara-negara berkembang. Rotavirus juga dapat menyebabkan wabah pada populasi orang dewasa (terutama orang tua), dan merupakan penyebab utama diare.

Tabel 6 : Beberapa outbreak Virus Hepatitis yang disebabkan oleh mengkonsumsi kerangkerangan.

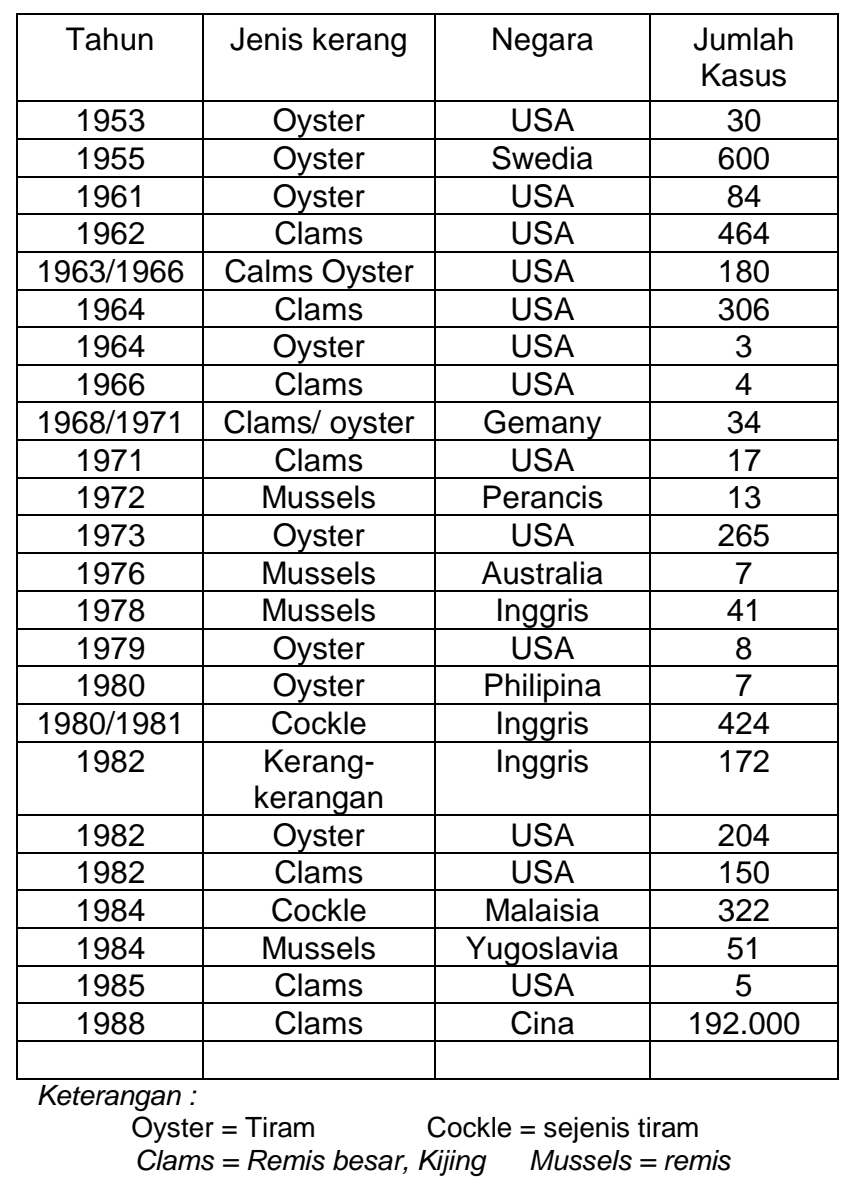

Sumber :Jehl-Pietri (1992) dan Schwartzbrod (1991)

Virus menyebar melalui fecal-oral, namun kemungkinan pula melalui pernafasan. Pernah terjadi beberapa wabah penyakit perut yang disebabkan rotavirus yang berasal dari air buangan. Beberapa wabah yang berhubungan dengan rotavirus dapat dilihat pada Tabel 7 .

Untuk mendeteksi rotavirus pada air buangan dan sampel lainnya digunakan microscopy elektron, pengujian ikatan enzym 
immunosorbent (ELISA Kits), atau kultur jaringan (sel yang populer adalah MA-104, yang diturunkan dari ginjal monyet). Deteksi pada jaringan sel termasuk di dalamnya metode seperti pengujian plaque, efek cytopathic (CPE), dan immunfluorescence.

Tabel 7 : Beberapa wabah Rotavirus di dunia

\begin{tabular}{|c|c|c|c|}
\hline Tahun & Lokasi & $\begin{array}{l}\text { Jumlah } \\
\text { Pasien }\end{array}$ & Keterangan \\
\hline 1977 & Swedia & 3.172 & $\begin{array}{l}\text { Suplai air bersih } \\
\text { disebuah kota kecil } \\
\text { terkontaminasi oleh air } \\
\text { limbah domestik }\end{array}$ \\
\hline 1980 & Brazil & $\sim 900$ & $\begin{array}{l}\text { Kontaminasi air di satu } \\
\text { sekolah swasta }\end{array}$ \\
\hline 1980 & $\begin{array}{l}\text { Norfolk } \\
\text { Island }\end{array}$ & - & Kontaminasi air tanah \\
\hline 1981 & Rusia & 173 & $\begin{array}{l}\text { Kontaminasi suplai air } \\
\text { bersih masyarakat }\end{array}$ \\
\hline 1981 & Colorado & 1.500 & $\begin{array}{l}\text { Kerusakan pada } \\
\text { sistem penyaringan } \\
\text { dan khlorinasi }\end{array}$ \\
\hline 1982 & Israel & $\sim 2000$ & $\begin{array}{l}\text { Kontaminasi Reservoir } \\
\text { oleh anak-anak }\end{array}$ \\
\hline $\begin{array}{l}1981- \\
1982\end{array}$ & $\begin{array}{l}\text { Jerman } \\
\text { Timur }\end{array}$ & 11.600 & $\begin{array}{l}\text { Kontaminasi air sumur } \\
\text { akibat banjir }\end{array}$ \\
\hline $\begin{array}{l}1982- \\
1983\end{array}$ & China & 13.311 & $\begin{array}{l}\text { Kontaminasi pada } \\
\text { sistem suplai air } \\
\text { bersih }\end{array}$ \\
\hline 1991 & Arizona & 900 & $\begin{array}{l}\text { Kontaminasi air sumur } \\
\text { oleh air limbah pada } \\
\text { sebuah resort }\end{array}$ \\
\hline
\end{tabular}

Sumber : Bitton (1994), Gerba (1995) dan Williams and Akin (1986)

\section{Agen Tipe Norwalk.}

Virus 27-nm kecil ini pertama kali ditemukan tahun 1968 di Norwalk, Ohio. Virus ini merupakan penyebab utama penyakit menular yang melalui air (waterborne) dan juga melalui makanan. Menyebabkan diare dan mual dan dapat menyerang usus halus, namun mekanisme pathogenicity belum diketahui. Karena virus ini tidak bisa berkembang biak pada cultur jaringan, maka masih sedikit yang diketahui mengenai struktur dan kandungan asam nucleic virusi ini.

Peralatan yang digunakan untuk mendeteksi sampel klinik adalah microscopy immune electron dan teknik radioimmunoassay, namun tidak cukup sensitif untuk sampel lingkungan. Virus norwalk memegang peranan penting pada penyebaran penyakit perut melalui air, juga berperan pada penularan diare. $42 \%$ dari wabah penyakit perut nonbakteri disebabkan oleh virus Norwalk.

\subsection{Parasit Protozoa}

Pada umumnya parasit protozoa menghasilkan kista sehingga dapat bertahan diluar hostnya dengan kondisi lingkungan yang berlawanan. Penyebab terjadinya kista adalah beberapa faktor seperti kekurangan makanan, akumulasi racun metabolit dan reaksi kekebalan host. Pada kondisi yang cocok, trophozoite baru dilepaskan dari kista. Proses ini disebut excystment. Protozoa patogen yang menular melalui air dan berpengaruh terhadap manusia adalah sebagai berikut (Tabel 6)

Tabel 6 : Penularan penyakit melalui air yang disebabkan Protozoa

\begin{tabular}{|l|l|l|}
\hline \multicolumn{1}{|c|}{ Oragisme } & \multicolumn{1}{|c|}{$\begin{array}{c}\text { Penyakit } \\
\text { (Lokasi yang } \\
\text { terkena) }\end{array}$} & \multicolumn{1}{|c|}{ Sumber utama } \\
\hline Giardia lamblia & $\begin{array}{l}\text { Giardiasis } \\
\text { (GI tract) }\end{array}$ & $\begin{array}{l}\text { Kotoran manusia dan } \\
\text { hewan }\end{array}$ \\
\hline $\begin{array}{l}\text { Entamoeba } \\
\text { histolytica }\end{array}$ & $\begin{array}{l}\text { Amoebic disentery } \\
\text { (GI tract) }\end{array}$ & Kotoran manusia \\
\hline $\begin{array}{l}\text { Achanthamoeba } \\
\text { castellani }\end{array}$ & $\begin{array}{l}\text { Amoebic } \\
\text { meningoencephalitis } \\
\text { (Sistem saraf pusat) }\end{array}$ & Tanah dan air \\
\hline Naeleria gruberi & $\begin{array}{l}\text { Amoebic } \\
\text { meningoencephalitis } \\
\text { (Sistem saraf pusat) }\end{array}$ & Tanah dan air \\
\hline Balantidium coli & $\begin{array}{l}\text { Dysentery/ perut } \\
\text { (GI tract) }\end{array}$ & Kotoran manusia \\
\hline Cryptosporidium & $\begin{array}{l}\text { Diarrhea : turun berat } \\
\text { badan, rasa mual } \\
\text { demam (GI tract) }\end{array}$ & $\begin{array}{l}\text { Kotoran manusia dan } \\
\text { hewan }\end{array}$ \\
\hline
\end{tabular}

\subsubsection{Giardia Lamblia}

Parasit protozoa flagelat ini mempunyai bentuk buah pear trophozoite (panjang 9-21 um) dan tahap kista bentuk telur (panjang 8-12 um dan lebar 7-10 um). Orang yang terinfeksi akan mengeluarkan kista (1-5) × $10^{6}$ per gram feces. Air buangan domestik merupakan sumber terbesar Giardia. Binatang buas dan binatang peliharaan berlaku sebagai tempat penampungan kista Giardia. Parasit ini menjadi wabah di daerah pegunungan di Amerika dan menginfeksi manusia, binatang buas dan binatang peliharaan. Infeksi disebabkan oleh ingestion kista yang ditemukan di dalam air. Dalam tubuh manusia, infeksi dapat berlangsung bulanan hingga tahunan.

Parasit ini Bergerak melalui perut dan kemudian melepaskan trophozoite, yang akan menempel pada sel epitel dari bagian atas usus halus dan berproduksi kembali secara fisi binary. Trophozoite melapisi epithelium saluran pencernaan sehingga mengganggu absorpsi lemak dan nutrient lain. Mereka membentuk kista selama mereka melewati pencernaan dan akhirnya mencapai usus besar.

Giardia mempunyai masa inkubasi satu sampai delapan minggu. Menyebabkan diare, sakit perut, pusing, kelelahan, dan berat badan menurun, namun giardiasis tidak beakibat fatal. Biasanya penularan terjadi melalui orang ke 
orang, namun Giardia dikenal sebagai salah satu agen etiologi yang penting dalam terjadinya wabah penyakit yang ditularkan melalui air (waterborne desease). Wabah terjadi akibat mengkonsumsi air yang dikhlorinasi namun tidak dilakukan penyaringan.

Pada umumnya wabah giardiasis berhubungan dengan mengkonsumsi air yang tidak diolah atau diolah namun belum sempurna. Kesalahan desain atau kesalahan konstruksi saringan dapat menyebabkan timbulnya Giardia lamblia dan selanjutnya akan mencemari air minum. Indikator bakteri secara tradisional tidak dapat mendeteksi adanya kista giardia dalam air atau dalam sampel lingkungan lainnya. Terdapat korelasi yang baik antara terjadinya kista Giardia dengan Cryptosporidium oocysts seperti juga dengan beberapa parameter kualitas air tradisional seperti kekeruhan.

Kista Giardia lambia dapat dikonsentrasi dari air dan air buangan dengan cara ultrafiltration atau adsorpsi dengan cartidge polypropilene. Oleh karena Giardia lamblia tidak dapat dibiakkan di laboratorium, maka kista harus dideteksi dan diindentifikasi dengan immunofluorescence dengan antibodi polyclonal atau monoclonal atau dengan phase-contrast microscopy. Kista yang terpapar oleh khlor dengan konsentrasi $1-11 \mathrm{mg} / \mathrm{l}$, walaupun memantul, namun tidak dapat dideteksi dengan phase-contrast microscopy karena unsur ini struktur dalamnya hilang.

Survey air buangan di beberapa negara bagian di Amerika Serikat menunjukkan bahwa jumlah kista Giardia bervariasi dari ratusan hingga ribuan kista per liter, namun konsentrasi kista tertinggi adalah $10^{5}$ per liter. Di Arizona, jumlah Giardia dideteksi 48 kista per $40 \mathrm{~L}$ dalam efluent lumpur aktif. Konsentrasi ini menurun menjadi 0,3 kista/40 L setelah penyaringan pasir. Parasit ini lebih tahan terhadap khlor dari pada bakteri.

\subsubsection{Cryptosporidium}

Parasit coccidian protozoan Cryptosporidium menginfeksi binatang (sapi, kambing, ayam, turkey, tikus, babi, anjing, kucing). Infeksi terhadap manusia dilaporkan pada tahun 1970 an. Cryptosporidium parvum adalah spesies utama yang mengakibatkan infeksi pada manusia dan binatang.

Tahap infeksi dari protozoan ini adalah kista (oocyst) ukuran $5-7$ um, yang tahan terhadap kondisi lingkungan. Selanjutnya ingestion dengan host yang cocok, oocyst melangsungkan excystation dan mengeluarkan infective sporozoites, yang menjadi parasit pada sel epithelial terutama dalam saluran pencernaan host. Beberapa peneliti menyatakan minimum dosis infeksi untuk Cryptosporidium pada manusia kurang dari atau sama dengan 1.000 oocyst. Pada binatang sejumlah $1-10$ oocyst dapat menimbulkan infeksi. Parasit ini menyebabkan diare yang selanjutnya menyebabkan penurunan berat badan dan kadangkala menimbulkan pusing, mual dan demam. Lamanya gejala dan akibatnya tergantung tingkat kekebalan si penderita. Umumnya diare berlangsung 1- 10 hari pada penderita yang kekebalannya baik, namun dapat lebih lama lagi hingga lebih dari sebulan pada penderita lemah kekebalannya ( misal penderita AIDS, kanker). Penelitian pada ribuan sampel kotoran manusia di Amerika Serikat, Kanada dan Eropa ditemukan bahwa lazimnya cryptosporidiosis pada manusia berkisar antara $1 \%-5 \%$.

Cara penularan Cryptosporidium umumnya melalui orang ke orang, melalui air, melalui makanan dan melalui binatang. Penularan orang ke orang merupakan penularan yang utama. Penularan patogen dari binatang yang terinfeksi kepada manusia, diperkirakan lebih besar untuk Cryptosporidium dari pada untuk Giardia.

Wabah di Carrollton, Georgia, AS menimpa hampir 13.000 orang dan terjadi karena mengkonsumsi air minum dari instalasi air minum yang menerapkan proses saringan pasir cepat yang kurang baik. Masalah yang ditemukan pada instalasi tersebut adalah adanya flokulasi yang tidak efektif dan memulai kembali penyaringan dengan saringan pasir tanpa melakukan cuci balik.

Patogen ini tidak efektif dihilangkan dengan cara pengolahan air konvensional seperti saringan pasir atau khlorinasi. Pengolahan dengan kapur untuk proses pelunakan air dapat me-non-aktifkan sebagian oocyst Cryptosporidium.

\subsubsection{Entamoeba Histolytica}

E. histolytica membentuk kista infeksi (diameter 10 - 15 um) bertahan dalam waktu yang lama dengan tidak ada gejala pada pembawanya; Sangat bertahan dalam air dan air buangan dan selanjutnya hidup pada host yang baru. Jumlah kista dalam air buangan dapat mencapai 5.000 kista per liter.

Parasit protozoa ini menular ke dalam tubuh manusia terutama melalui air atau makanan yang terkontaminasi. Substansi ini menyebabkan amebiasis atau disentri amoebic, yang merupakan penyakit usus besar. Gejala bervariasi mulai dari diare bergantian dengan sembelit hingga disentri akut. Dapat pula menyebabkan borok pada lapisan mucosa saluran pencernaan, menimbulkan diare dan 
kram. Hal ini menyebabkan banyak kematian terutama di negara-negara berkembang dan terjadi terutama karena mengkonsumsi air minum yang terkontaminasi.

\subsubsection{Naegleria}

Naeglaria fowleri adalah penyebab primary amoebic meningoencephalitis (PAME), yang pertama kali dilaporkan di Australia pada tahun 1965. Berakibat fatal setelah $4-5$ tahun masuk ke dalam tubuh.

Protozoa ini masuk ke dalam tubuh melalui membran mucous hidung dan selanjutnya berpindah ke dalam sistem syaraf pusat. Penyakit ini berhubungan dengan kegiatan berenang dan menyelam. Hal lain yang menghawatirkan, Naeglaria dapat bergabung dengan Legionella pneumophila dan patogen lainnya. Akibat dari penggabungan ini terhadap manusia, masih dalam penelitian.

Terdapat teknik identifikasi yang cepat (contoh Cytometry, sistem APIZYM, yang berdasarkan pada deteksi enzym aktif) yang dapat membedakan antara Naeglaria fowleri dengan spesies Naeglaria lainnya.

\subsection{Cacing Parasit (Helminth Parasites)}

Walaupun cacing (Helminth) parasit tidak biasa diteliti oleh para ahli mikrobiologi, namun demikian keberadaannya dalam air buangan bersamaan dengan viral pathogen dan protozoan parasites, menjadi perhatian dalam hal pengaruhnya terhadap kesehatan manusia. Bentuk telurnya merupakan tahap infeksi dari parasit helminth; mereka keluar bersama dengan kotoran dan menyebar melalui air buangan, tanah atau makanan. Telur ini sangat tahan terhadap tekanan lingkungan dan terhadap khlorinasi dalam pengolahan air buangan. Parasit-parasit yang perlu diperhatikan adalah sebagai berikut :

\subsubsection{Taenia Spp.}

Terdapat 2 jenis yaitu Taenia saginata (cacing pita sapi) dan Taenia solium (cacing pita babi) sekarang ini jarang ditemukan di Amerika Serikat. Parasit ini berkembang dalam host antara sehingga menjadi tahap larva yang disebut cysticercus dan akhirnya mencapai tubuh manusia, yang berperan sebagai host terakhir. Ternak sapi menelan telur parasit pada saat makan rumput dan berperan sebagai host antara untuk Taenia saganita, babi menjadi host antara untuk Taenia solium. Cysticerci masuk ke dalam otot, mata dan otak. Parasit ini mengganggu pencernaan, sakit perut dan berat badan turun.

\subsubsection{Ascaris Lumbricoides (Cacing Gelang)}

Di dalam siklus kehidupan cacing ini , pada saat fase larva dapat berpindah ke paru-paru dan menyebabkan pneumonitis. Penyakit ini dapat terjangkit dengan cara terkena hanya beberapa telur. Individu yang terinfeksi mengeluarkan sejumlah besar telur, dan setiap Ascaris betina dapat menghasilkan hampir 200.000 telur per hari. Telur-telur ini menggumpal dan dapat dihilangkan dengan cara sedimentasi pada proses pengolahan air buangan. Walaupun dapat dihilangkan secara efektif dengan proses lumpur aktif, telur-telur ini tahan terhadap khlor.

\subsubsection{Toxocara Canis}

Parasit ini terutama menginfeksi anakanak yang punya kebiasaan makan makanan kotor. Selain dapat mengganggu pencernaan larva parasit ini dapat berpindah ke mata, yang dapat menyebabkan kerusakan ocular, kadangkala dapat menyebabkan kehilangan mata.

\subsubsection{Trichuris Trichiura}

Trichuris trichiura menyebabkan infeksi whipworm pada manusia. Telur-telurnya menggumpal dan dapat mengendap pada tanki sedimentasi.

\subsection{Masalah Lain Yang Disebabkan Oleh Mikroorganisme}

Air permukaan yang merupakan air baku instalasi pengolahan air minum dapat menjadi tempat sejumlah besar konsentrasi ganggang biru-hijau seperti Anabaena flos-aquae, Microcystis aeruginosa, dan Schizothrix calcicola. Ganggang ini menghasilkan exotoxins (peptides dan alkaloid) juga endotoxins (lipopolysaccharides) yang menyebabkan sindrome seperti gastroenteritis. Namun karena kurang pengetahuan tantang keberadaan dan potensi untuk memisahkan racun ini dari pengolahan air dan air buangan, risiko terhadap kesehatan belum dievaluasi.

\section{MASALAH AIR LIMBAH DOMESTIK DAN ALTERNATIF PENANGGULANGANNYA}

Masalah pencemaran lingkungan di kotakota besar di Indonesia, telah menunjukkan gejala yang cukup serius, khususnya masalah pencemaran air. Penyebab dari pencemaran tadi tidak hanya berasal dari buangan industri dari pabrik-pabrik yang membuang begitu saja air limbahnya tanpa pengolahan lebih dahulu ke sungai atau ke laut, tetapi juga yang tidak kalah memegang andil baik secara sengaja atau tidak 
adalah masyarakat Jakarta itu sendiri, yakni akibat air buangan rumah tangga yang jumlahnya makin hari makin besar sesuai dengan perkembangan penduduk maupun perkembangan kota itu sendiri. Ditambah lagi rendahnya kesadaran sebagian masyarakat yang langsung membuang kotoran/tinja maupun sampah ke dalam sungai, menyebabkan proses pencemaran sungai-sungai yang ada di Jakarta bertambah cepat.

Padatnya pemukiman dan kondisi sanitasi lingkungan yang jelek serta buangan industri yang langsung dibuang ke badan air tanpa proses pengolahan telah menyebabkan pencemaran sungai serta badan-badan air yang ada, bahkan di beberapa wilayah telah menyebabkan pencemaran air tanah dangkal.

Dari hasil penelitian yang dilakukan oleh Dinas PU DKI dan Tim JICA (1989), jumlah unit air buangan dari buangan rumah tangga per orang per hari adalah 118 liter dengan konsentrasi BOD rata-rata $236 \mathrm{mg} / \mathrm{lt}$ dan pada tahun 2010 nanti diperkirakan akan meningkat menjadi 147 liter dengan konsentrasi BOD ratarata $224 \mathrm{mg} / \mathrm{lt}$. Jumlah air buangan secara keseluruhan diperkirakan sekitar 1,3 juta M3/hari, dimana $80 \%$ lebih dari jumlah limbah berasal dari air limbah domestik serta air buangan perkantoran dan daerah komersial. Sedangkan sisanya merupakan air limbah yang berasal dari buangan industri.

Permasalahan yang ada sampai saat ini adalah laju perkembangan pembangunan sarana pengelolaan air limbah secara terpusat sangat lambat (hanya sekitar $3,5 \%$ dari luas total daerah pelayanan), serta teknologi pengolahan air limbah rumah tangga invidual (On Site treatment), ataupun semi komunal yang ada tidak memadai atau sangat kurang sekali, sehingga pelaksanaan pengelolaan limbah untuk wilayah yang belum terlayanai oleh jaringan air limbah belum dapat dilaksanakan.

Sistem pembuangan air limbah yang umum digunakan masyarakat yakni air limbah yang berasal dari toilet dialirkan ke dalam tangki septik dan air limpasan dari tangki septik diresapkan ke dalam tanah atau dibuang ke saluran umum. Sedangkan air limbah non toilet yakni yang berasal dari mandi, cuci serta buangan dapur dibuang langsung ke saluran umum.

Berdasarkan survai di Jakarta tahun 1989, tiap orang rata-rata mengeluarkan beban limbah organik sebesar 40 gram BOD per orang per hari, yakni dari limbah toilet 13 gram per orang per hari dan dari limbah non toilet sebesar 27 gram BOD per orang per hari. Jika hanya air limbah toilet yang diolah dengan sistem tangki septik dengan efisiensi pengolahan $65 \%$, maka hanya $22,5 \%$ dari total beban polutan organik yang dapat dihilangkan, sisanya 77,5 \% masih terbuang keluar. Hal ini secara umum dapat diterangkan seperti pada Gambar 4.

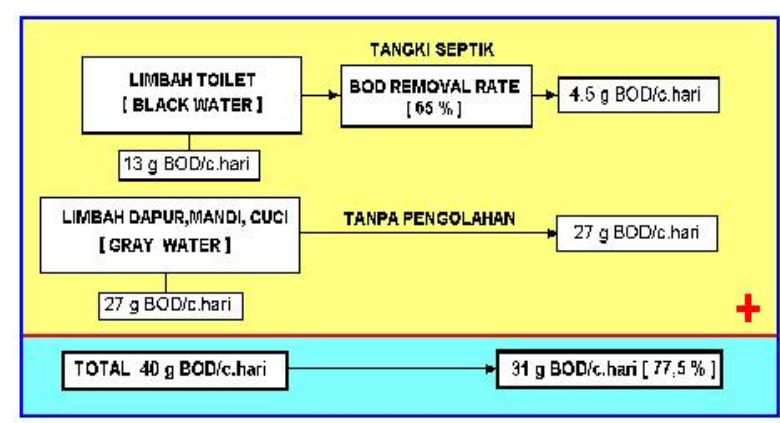

Gambar 4 : Efisiensi pembuangan air limbah rumah tangga dengan sistem "On Site Treatment" sederhana.

Untuk mengatasi masalah air limbah rumah tangga, salah satu cara adalah dengan merubah sistem pembuangan air limbah yang lama, yakni dengan cara seluruh air limbah rumah tangga baik air limbah toilet maupun air limbah non toilet diolah dengan unit pengolahan air limbah di tempat (on site treatment), selanjutnya air olahannya dibuang ke saluran umum. Jika efisiensi pengolahan "On site treatment " rata-rata $90 \%$, maka hanya tinggal $10 \%$ dari total beban polutan yang masih terbuang keluar. Sistem pembuangan air limbah dengan sistem "on site treatmet "secara sederhana ditunjukkan seperti pada Gambar 5.

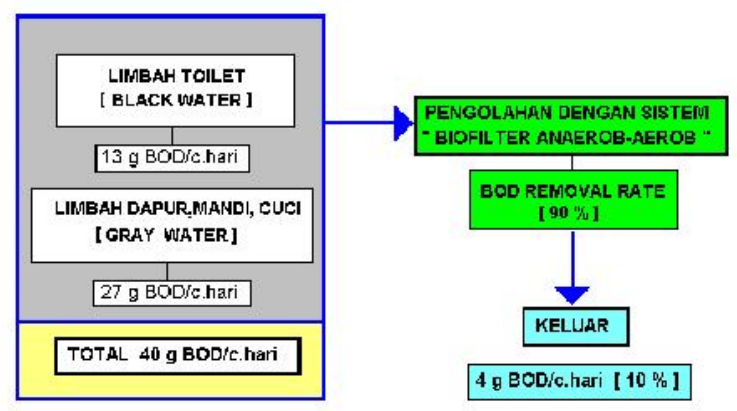

Gambar 5 : Efisiensi pembuangan air limbah rumah tangga dengan sistem "On Site Treatment".

Salah satu teknologi pengolahan air limbah rumah tangga dengan sistem "On Site Treatment " adalah dengan menggunakan proses kombinasi biofilter anaerob dan aerob. Sistem ini dapat diaplikasikan untuk tiap-tiap rumah tangga maupun semi komunal yakni beberapa rumah menggunakan satu unit alat pengolahan air limbah. 


\subsection{Pengolahan Air Limbah domestik dengan Sistem Biofilter Anaerob-Aerob}

Air limbah rumah tangga yang akan diolah dikumpulkan dari beberapa rumah dengan cara mengalirkannya melalui pipa PVC.Jenis air limbah yang diolah yakni seluruh air limbah rumah tangga yang berasal dari air bekas cucian, buangan dapur, buangan kamar mandi dan buangan (limbah) tinja.

Air limbah dialirkan ke alat pengolahan melalui lubang pemasukan (inlet) masuk ke ruang (bak) pengendapan awal. Selanjutnya air limpasan dari bak pengendapan awal air dialirkan ke zona anaerob. Zona anaerob tersebut terdiri dari dua ruangan yang diisi dengan media dari bahan plastik sarang tawon untuk pembiakan mikroba. Pada zona anaerob pertama air limbah mengalir dengan arah aliran dari atas ke bawah, sedangkan pada zona anaerob ke dua air limbah mengalir dengan arah aliran dari bawah ke atas. Selanjutnya air limpasan dari zona anaerob ke dua mengalir ke zona aerob melalui lubang (weir).

Di dalan zona aerob tersebut air limbah dialirkan ke unggun media plastik sarang tawon dengan arah aliran dari bawah ke atas, sambil dihembus dengan udara. Air limbah dari zona aerob masuk ke bak pengendapan akhir melalui saluran yang ada di bagian bawah.

Air limbah yang ada di dalam bak pengendapan akhir tersebut disirkulasikan ke zona anaerob pertama, sedangkan air limpasan dari bak pengendapan akhir tersebut merupakan air hasil olahan dan keluar melalui lubang pengeluaran, selanjutnya masuk ke bak kontaktor khlor. Selanjutnya air limpasan dari bak kontaktor dibuang ke saluran umum.

Setelah proses berjalan selama dua sampai empat minggu pada permukaan media sarang tawon akan tumbuh lapisan mikroorganisme, yang akan menguaraikan senyawa polutan yang ada dalam air limbah.

\subsection{Prototipe Alat}

Prototipe alat ini dibuat dari bahan fiber glas (FRP) dan dibuat dalam bentuk yang kompak dan langsung dapat dipasang dengan ukuran panjang $310 \mathrm{~cm}$, lebar $100 \mathrm{~cm}$ dan tinggi $200 \mathrm{~cm}$. Ruangan di dalam alat tersebut dibagi menjadi beberapa zona yakni rungan pengendapan awal, zona biofilter anaerob, zona biofilter aerob dan ruangan pengendapan akhir. Media yang digunakan untuk biofilter adalah media plastik sarang tawon. Air limbah yang ada di dalam rungan pengendapan akhir sebagian disirkulasi ke zona aerob dengan menggunakan pompa sirkulasi.

Prototipe alat tersebut dirancang untuk dapat mengolah air limbah sebesar $6 \mathrm{~m} 3 /$ hari, atau untuk melayani sekitar 40-50 orang. Desain alat dapat disesuaikan dengan kapasitas air limbah yang akan diolah atau disesuaikan dengan luas lahan yang tersedia. Untuk kapasitas pengolahan yang lebih besar atau lebih kecil dapat dirancang sesuai dengan kebutuhan. Gambar rancangan sistem pengolahan air limbah dengan kombinasi proses biofilter anaerob-aerob tersebut ditunjukkan seperti pada Gambar 6 dan Gambar 7.

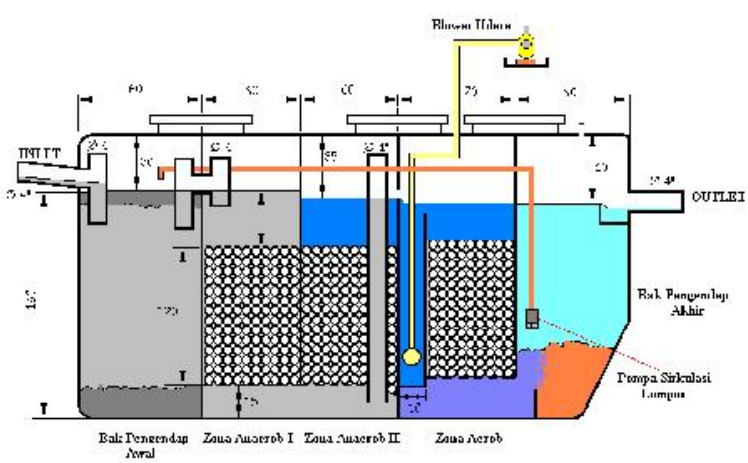

Gambar 6: Penampang unit alat pengolahan air limbah rumah tangga dengan proses biofilter anaerob-aerob dari bahan Fiberglas.

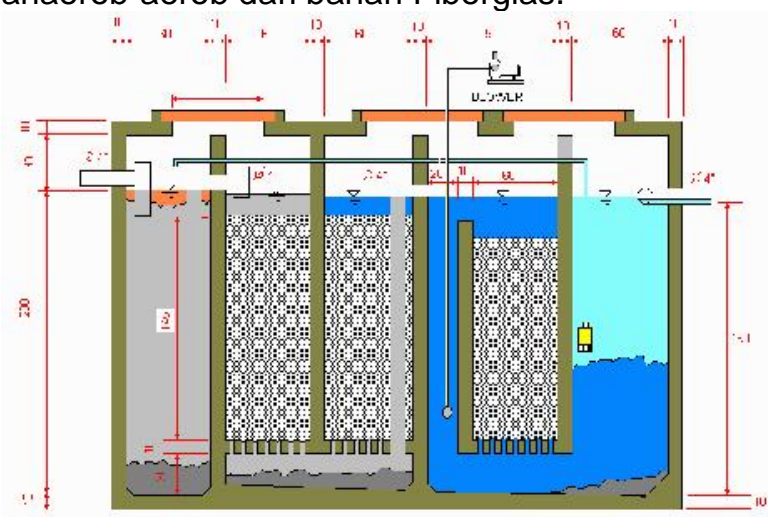

Gambar 7: Penampang unit alat pengolahan air limbah rumah tangga dengan proses biofilter anaerob-aerob dari bahan Beton-Semen.

\subsection{Uji Coba Di Lapangan}

Air limbah rumah tangga yang akan diolah dikumpulkan dari beberapa rumah dengan cara mengalirkannya melalui pipa PVC. Jenis air limbah yang diolah yakni seluruh air limbah rumah tangga yang berasal dari air bekas cucian, buangan dapur, buangan kamar mandi dan buangan (limbah) tinja.

Air limbah dialirkan ke alat pengolahan melalui lubang pemasukan (inlet) masuk ke ruang (bak) pengendapan awal. Selanjutnya air limpasan dari bak pengendapan awal air dialirkan ke zona anaerob. Zona anaerob 
tersebut terdiri dari dua ruangan yang diisi dengan media dari bahan plastik tipe sarang tawon. Pada zona anaerob pertama air limbah mengalir dengan arah aliran dari atas ke bawah, sedangkan pada zona anaerob ke dua air limbah mengalir dengan arah aliran dari bawah ke atas. Selanjutnya air limpasan dari zona anaerob ke dua mengalir ke ke zona aerob melalui lubang (weir).

Di dalan zona aerob tersebut air limbah dialirkan ke unggun media dari bahan plastik tipe sarang tawon dengan arah aliran dari bawah ke atas, sambil dihembus dengan udara. Air limbah dari zona aerob masuk ke bak pengendapan akhir melalui saluran yang ada di bagian bawah.

Air limbah yang ada di dalam bak pengendapan akhir tersebut disirkulasikan ke zona anaerob pertama, sedangkan air limpasan dari bak pengendapan akhir tersebut merupakan air hasil olahan dan keluar melalui lubang pengeluaran, selanjutnya masuk ke bak kontaktor khlor. Selanjutnya air limpasan dari bak kontaktor dibuang ke saluran umum.

Setelah proses berjalan selama dua minggu pada permukaan media (batu pecah) akan tumbuh lapisan mikro-organisme, yang akan menguaraikan senyawa polutan yang ada dalam air limbah. Analisa kualitas air limbah dilakukan secara periodik dengan cara mengambil contoh air limbah yang masuk, air limbah pada tiap-tiap zona dan air olahan, sedangkan perameter yang akan diperiksa yakni BOD, COD, padatan tersuspensi (SS), ammonium nitrogen $\left(\mathrm{NH}_{4}-\mathrm{N}\right)$, deterjen (MBAS), dan phospat $\left(\mathrm{PO}^{4}\right)$. Skema proses pengolahannya ditunjukkan seperti pada gambar 8.

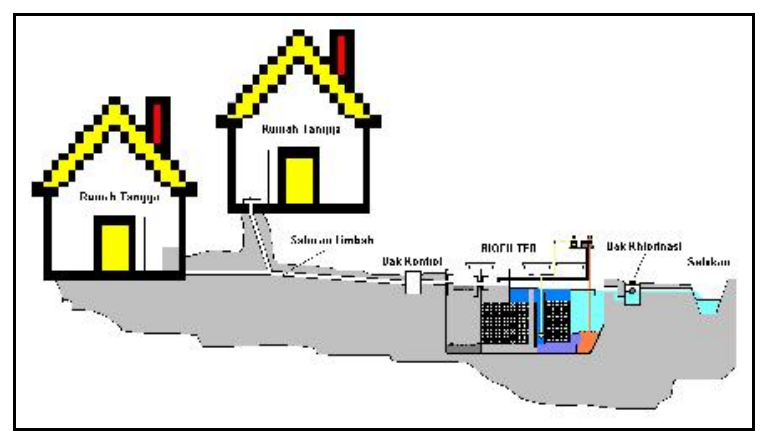

Gambar 8 : Bagan aliran air limbah dan proses pengolahan yang digunakan untuk percobaan.

\section{Kondisi Operasi :}

- Waktu Tinggal Total = 1-3 hari.

- Air yang ada di dalam bak pengendapan akhir sebagian disir-kulasikan ke zona anaerob pertama dengan menggunakan pompa sirkulasi.
- Ratio Sirkulasi Hidrolis (hydraulic Recycle Ratio, $\mathrm{HRR})=1$

- Pengambilan contoh dilakukan setelah 4 minggu (satu bulan) operasi, dan setelah 5 (lima) minggu operasi.

Dari hasil uji coba prototipe alat pengolah air limbah rumah tangga "Kombinasi Biofilter Anaerob-Aerob" tersebut di atas dapat disimpulkan bahwa :

dengan waktu tinggal antara 1- 3 hari, dan proses sirkulasi dengan rasio resirkulasi hidrolik, HRR = 1 didapatkan efisisensi pengolahan yang cukup tinggi yakni BOD 84,7 - $91 \%$, COD 79,6 95,3 \%, SS 94,1 - $95 \%$, Ammonia $\left(\mathrm{NH}_{4}-\mathrm{N}\right)$ 89,3 89,8 \%, Deterjen (MBAS) 83 - $87 \%$ dan Phospat $\left(\mathrm{PO}_{4}\right) \quad 44,4-47,3 \%$.

Efisiensi pengolahan khususnya penghilangan senyawa organik (BOD, COD) dan SS cukup stabil meskipun debit dan konsentrasi polutan dalam air limbah sangat berfluktuasi. Unit alat pengolah air limbah rumah tangga dengan sistem kombinasi biofilter anaerob-aerob ini dapat dibuat dengan skala kecil ataupun skala besar sesuai dengan kebutuhan. Untuk pengolahan air limbah rumah tangga dengan kapasitas 40 orang (5-6 $\mathrm{M}^{3}$ per hari) memerlukan energi listrik sekitar 65 watt.

\section{PENUTUP}

Dari uraian tersebut di atas dapat kita lihat bahwa masalah air limbah domestik merupakan sumber pencemaran yang sangat potensial. Hal ini disebabkan karena aiir limbah domestik mengandung senyawa polutan organik maupun anorganik serta mengadung banyak mikroorganisme patogen misalnya bakteria patogen, virus, cacing parasit, protozoa parasit dan lainnya , yang dapat mengakibatkan terjangkitnya penyakit bawaan air terhadap manusia.

Masalah air limbah domestik di Indonesia menjadi lebih serius disebabkan laju perkembangan pusat pengolahan air limbah perkotaan (domestik) sangat rendah. Di DKI Jakarta misalnya, hanya $3,5 \%$ yang sudah terlayani oleh sistem pengolahan air limbah terpusat. Untuk skala nasional belum ada data yang akurat, yang jelas prosesentase penayanannya lebih rendah lagi.

Untuk menanggulangi masalah tersebut salah satu alternatif pengolahan air limbah domestik dapat dilakukan secara individual atau semi komunal dengan menggunakan proses biofilter anaerob-aerob. Beberapa keunggulan proses pengolahan air limbah dengan biofilter anaerb-aerob antara lain yakni :

- Pengelolaannya sangat mudah.

- Biaya operasinya rendah. 
- Dibandingkan dengan proses lumpur aktif, Lumpur yang dihasilkan relatif sedikit.

- Dapat menghilangkan nitrogen dan phospor yang dapat menyebabkan euthropikasi.

- Suplai udara untuk aerasi relatif kecil.

- Dapat digunakan untuk air limbah dengan beban BOD yang cukup besar.

- Dapat menghilangan padatan tersuspensi (SS) dengan baik.

- Kapasitas disain dapat dirancang sesuai dengan kebutuhan .

Alat ini dapat diterapkan untuk pengolahan beberapa jenis air limbah misalnya :

- Pengolahan Air Limbah Rumah tangga (domestik).

- Pengolahan Air Limbah Perkantoran Skala Kecil sampai Besar.

- Pengolahan Alr Limbah Pemukiman Kumuh.

- Pengolahan limbah Puskesmas, rumah bersalin, limbah rumah sakit.

- Pebngolahan Air Limbah Organik Untuk Industri Kecil misalnya industri kecil tahutempe, industri makanan.

- Pengolahan limbah MCK, dll.

\section{DAFTAR PUSTAKA}

- ---- " The Study OnUrban Drainage And Waste Water Disposal Project In The City Of Jakarta", , JICA, December 1990.

- -----, " Gesuidou Shissetsu Sekkei Shisin to Kaisetsu “, Nihon Gesuidou Kyoukai, 1984.

- -----, "Pekerjaan Penentuan Standard Kualitas Air Limbah Yang Boleh Masuk Ke Dalam Sistem Sewerage PD PAL JAYA", Dwikarasa Envacotama-PD PAL JAYA, 1995.

- Bitton, G. 1990. Introduction to Environmental Virology. Wiley, New York.

- Bitton. G. 1994. Wastewater Microbiology. Wiley-Liss, New York.

- Cliver, D.O. 1984. Significance of water and environment in the transmission of virus disease. Monogr. Virol.

- Craun, G.F., Ed. 1986. Waterborne Disease in The United States. CRC Press, Boca Raton.

- Fair, Gordon Maskew et.al., " Eements Of Water Supply And Waste Water Disposal', John Willey And Sons Inc., 1971.

- Gerba, C.P., S.N. Singh, and J.B. Rose. 1985. Waterborne gastroenteristis and viral hepatitis. CRC Crit. Rev. Environ. Control.

- Gouda T., "Suisitsu Kougaku - Ouyouben", Maruzen kabushiki Kaisha, Tokyo, 1979.
- MetCalf And Eddy, "Waste Water Engineering", Mc Graw Hill 1978.

- Said, N.I., "Sistem Pengolahan Air Limbah Rumah Tangga Skala Individual Tangki Septik Filter Up Flow", Majalah Analisis Sistem Nomor 3, Tahun II, 1995.

- Sobsey, M.D., and B. Olson. 1983. Microbial agents of waterborne disease, in : Assessement of Microbiology and Turbidity Standards fo Drinking Water, P.S.Berger and Argaman, Eds. EPA Report \# EPA 570-9-83001. 